\title{
THE MODE OF ACTION OF A NEW ANTITUMOR ANTIBIOTIC, SPORAMYCIN
}

\author{
Masaaki OKamoto, * Kanki Komiyama, Hideo Takeshima, \\ Hiroshi Yamamoto and Iwao Umezawa \\ Kitasato Institute, Shirokane, Minato-ku, Tokyo 108, Japan \\ (Received for publication January 16, 1979)
}

\begin{abstract}
Sporamycin, an antitumor antibiotic, primarily inhibited DNA synthesis, while RNA and protein synthesis were not significantly affected in HeLa S3 cells. The antibiotic also calused strand scission of cellular DNA. However, the effects were not observed when the colls were incubated at $0^{\circ} \mathrm{C}$ before washing and subsequently incubated at $37^{\circ} \mathrm{C}$. The $T \mathrm{~m}$ o: calf thymus DNA decreased when incubated with sporamycin in vitro. Sporamycin did not affect DNA synthesis in vitro catalyzed by partially purified DNA polymerase $\alpha, \beta$, and $\gamma$ derived from EHRLICH ascites cells.
\end{abstract}

Sporamycin ${ }^{1,2)}$, a polypeptide antitumor antibiotic isolated from the culture filtrate of Streptosporangium pseudovulagare, strain No. PO-357, inhibits both bacterial and mammalian cell growth ${ }^{3)}$, and shows antitumor activity against certain experimental tumors such as leukemia P-388 and L-1210, and sarcoma-180. The objective of this work was to examine the effect of sporamycin mainly on DNA syrithesis and on strand scission of cellular DNA.

\section{Materials and Methods}

$\left[{ }^{3} \mathrm{H}\right]$-Thymidine $(27 \mathrm{Ci} / \mathrm{mmol}),\left[{ }^{14} \mathrm{C}\right]$-thymidine $(59 \mathrm{mCi} / \mathrm{mmol}),\left[{ }^{3} \mathrm{H}\right]$-leucine $(57 \mathrm{Ci} / \mathrm{mmol})$, and $\left[{ }^{3} \mathrm{H}\right]$-uridine $(28 \mathrm{Ci} / \mathrm{mmol})$ were obtained from the Radiochemical Center, Amersham, U.K., $\left[{ }^{3} \mathrm{H}\right]$ TTP $(17 \mathrm{Ci} / \mathrm{mmol}$ ) from New England Nuclear, Mass., poly(rA) and oligo (dT12-18) from Boehringer Mannheim, Germany.

\section{Cell line}

HeLa cells were cultured in monolayers in EAGLE's minimum essential medium (MEM) supplemented with $10 \%$ bovine serum and antibiotics (100 units $/ \mathrm{ml}$ of penicillin and $100 \mu \mathrm{g} / \mathrm{ml}$ of streptomycin) a: $37^{\circ} \mathrm{C}$ in $95 \%$ air $-5 \% \mathrm{CO}_{2}$ atmosphere.

Sporamycin was purified according to the procedure as previously reported ${ }^{2)}$, and the antibiotic gave a single SCHLIEREN peak during sedimentation in a Spinco model E ultracentrifuge.

Determination of the synthesis of cellular macromolecules

HeLa S3 cells $\left(3 \times 10^{4}\right)$ were plated into $30-\mathrm{mm}$ Petri dishes, each inserted with $18-\mathrm{mm}$ cover glass with $2 \mathrm{ml}$ of MEM and allowed to reach exponential growth. Triplicate specimen were treated with ${ }^{3} \mathrm{H}$-thymidine (TdR, $0.5 \mu \mathrm{Ci} / \mathrm{ml}$ ), ${ }^{3} \mathrm{H}$-uridine (UR, $0.5 \mu \mathrm{Ci} / \mathrm{ml}$ ) or ${ }^{3} \mathrm{H}$-leucine (Leu, $1 \mu \mathrm{Ci} / \mathrm{ml}$ ) for 30 minutes at 4 hours after the addition of sporamycin. Then the cells were rinsed 3 times with ice-cold Hanks' solution and 2 times with ice-cold 5\% trichloroacetic acid. The radioactiviy of acid-insoluble fraction was determined by the Aloka gas-flow counter.

Effect of temperature on the activity of sporamycin

At 30 minutes after the incubation of HeLa cells with $10 \mu \mathrm{g} / \mathrm{ml}$ of sporamycin at $0^{\circ} \mathrm{C}$ or $37^{\circ} \mathrm{C}$, the cells were rinsed with fresh MEM, and placed in two culture flasks. One flask was added with $0.5 \mu \mathrm{Ci}$ of ${ }^{3} \mathrm{H}-\mathrm{TdR}$, and this mixture was incubated for 30 minutes at $37^{\circ} \mathrm{C}$ to determine the ratio of

* Present address: Institute for Protein Research, Osaka University, Yamada Kami, Suita, Osaka 565. 
DNA synthesis. The other culture flask was incubated further for 3 days at $37^{\circ} \mathrm{C}$, and the number of cells were counted by the Coulter counter.

\section{Preparation of DNA polymerase}

DNA polymerases were partially purified from EHRLICH ascites cells by the method of MATSUKAGE ${ }^{4)}$. Briefly, EHRLICH ascites cells were extracted with a buffer containing $0.5 \mathrm{~mm} \mathrm{KCl}, 50 \mathrm{~mm}$ Tris- $\mathrm{HCl}, \mathrm{pH}$ 7.8, $1 \mathrm{~mm}$ dithiothreitol and $1 \mathrm{~mm}$ EDTA. DNA polymerases were fractionated with $25 \sim 65 \%$ saturated ammonium sulfate. DNA polymerase $\alpha$ was purified by column chromatography over DEAE-cellulose, P-cellulose, and hydroxyapatite. DNA polymerase $\beta$ and $\gamma$ were applied to column chromatography over DEAE-cellulose and P-cellulose. Terminal deoxynucleotidyl transferase from calf thymus was obtained from Boeringer Mannheim, Yamanouchi K.K.

Assay of DNA synthesis

DNA polymerase $\alpha$ : The reaction mixture (total volume, $25 \mu \mathrm{l}$ ) contained $50 \mathrm{~mm}$ Tris- $\mathrm{HCl}(\mathrm{pH}$ 7.9), $6 \mathrm{~mm}\left(\mathrm{CH}_{3} \mathrm{COO}\right)_{2} \mathrm{Mg}, 1 \mathrm{~mm}$ dithiothreitol, $0.1 \mathrm{~mm}$ each of deoxynucleoside triphosphates (dTTP carried a tritium label of $2 \mathrm{Ci} / \mathrm{mmol}$ ), $16 \%$ glycerol, $400 \mu \mathrm{g} / \mathrm{ml}$ bovine serum albumin, $2 \mu \mathrm{g} / \mathrm{ml}$ calf thymus-activated DNA, and DNA polymerase $(0.1 \sim 1 \mu \mathrm{g}$ protein).

DNA polymerase $\beta$ or $\gamma$ : The reaction mixture (total volume, $25 \mu \mathrm{l}$ ) contained $50 \mathrm{~mm}$ Tris$\mathrm{HCl}(\mathrm{pH} 7.9), 0.5 \mathrm{~mm} \mathrm{MnCl}, 1 \mathrm{~mm}$ dithiothreitol, $0.1 \mathrm{~mm}{ }^{3} \mathrm{H}$-dTTP (2 Ci/mmol), $16 \%$ glycerol, $400 \mu \mathrm{g} / \mathrm{ml}$ bovine serum albumin, $80 \mathrm{~mm} \mathrm{KCl}, 2 \mu \mathrm{g}$ poly(rA), $0.4 \mu \mathrm{g}$ oligo (dT 12-18), and DNA polymerase $(1 \sim 5 \mu \mathrm{g}$ protein).

Terminal deoxynucleotidyl transferase: The reaction mixture (total volume, $25 \mu \mathrm{l}$ ) contained $50 \mathrm{~mm}$ Tris- $\mathrm{HCl}$ ( $\mathrm{pH} 7.5$ ), $0.5 \mathrm{~mm} \mathrm{MnCl}_{2}, 80 \mathrm{~mm} \mathrm{KCl}, 1 \mathrm{~mm}$ dithiothreitol, $400 \mu \mathrm{g} / \mathrm{ml}$ bovine serum albumin, $0.1 \mathrm{~mm}{ }^{3} \mathrm{H}$-dTTP $(2 \mathrm{Ci} / \mathrm{mmol}), 2 \mu \mathrm{g}$ calf thymus-activated DNA, and the enzyme. After incubation of this reaction mixture at $37^{\circ} \mathrm{C}$ for 30 minutes, the acid-insoluble radioactivity was determined.

\section{Determination of strand scission of cellular DNA}

HeLa cells were incubated with ${ }^{14} \mathrm{C}$-TdR $(0.2 \mu \mathrm{Ci} / \mathrm{ml})$ or ${ }^{3} \mathrm{H}-\mathrm{TdR}(1 \mu \mathrm{Ci} / \mathrm{ml})$ for 16 hours. HeLa cells labeled with ${ }^{3} \mathrm{H}$-TdR were treated with sporamycin at $37^{\circ} \mathrm{C}$ for 4 hours. At the end of incubation period, equal number of non-treated $\mathrm{HeLa}$ cells prelabeled with ${ }^{14} \mathrm{C}-\mathrm{TdR}$ and sporamycintreated HeLa cells were mixed. The cells were placed on the top of $5 \sim 20 \%$ sucrose gradient consisting of $0.7 \mathrm{M} \mathrm{NaCl}, 0.001 \mathrm{~m}$ EDTA and $0.3 \mathrm{M} \mathrm{NaOH}$ overlayerd with the lysis solution ( $2 \%$ SDS). The preparation was sedimented in an RPS 40 rotor at $20,000 \mathrm{rpm}$ for 30 minutes in a Hitachi ultracentrifuge.

\section{Thermal profile of DNA}

Calf thymus DNA was dissolved in $1 / 100 \mathrm{SSC}$ (SSC: $0.15 \mathrm{M} \mathrm{NaCl}, 0.015 \mathrm{M}$ sodium citrate, $\mathrm{pH}$ 7.0) and incubated with sporamycin at $37^{\circ} \mathrm{C}$ for 30 minutes. After the incubation the temperature of the reaction mixture was raised at the rate of $2^{\circ} \mathrm{C} /$ minute with a linear temperature programmer. The thermal denaturation profile of DNA was automatically recorded, using Hitachi Model 124 spectrophotometer.

\section{Results}

Effect of Sporamycin on the Synthesis of Cellular Macromolecules

HeLa cells were incubated with ${ }^{3} \mathrm{H}$-TdR, ${ }^{3} \mathrm{H}$-UR or ${ }^{3} \mathrm{H}$-Leu for 30 minutes after the cells were preincubated for 4 hours in the presence of sporamycin, and the incorporation ratio was compared with that of non-treated cells. As shown in Fig. 1, the incorporation of ${ }^{3} \mathrm{H}-\mathrm{TdR}$ into DNA was strongly inhibited at a concentration of $0.3 \mu \mathrm{g} / \mathrm{ml}$ of the antibiotic in spite of very slight inhibition of the incorporation of ${ }^{3} \mathrm{H}-\mathrm{UR}$ into RNA and ${ }^{3} \mathrm{H}-\mathrm{Leu}$ into protein. When HeLa cells were incubated with various concentrations of sporamycin, the incorporation of ${ }^{3} \mathrm{H}-\mathrm{TdR}$ into DNA was markedly inhibited at concentrations of more than $0.1 \mu \mathrm{g} / \mathrm{ml}$ for 60 minutes. 
Effect of Temperature on the Activity

$$
\text { of Sporamycin }
$$

$\mathrm{HeLa}$ cells were incubated with sporamycin at $37^{\circ} \mathrm{C}$ or $0^{\circ} \mathrm{C}$ for 30 minutes, rinsed, and incorporation of ${ }^{3} \mathrm{H}-\mathrm{TdR}$ into DNA and their cell growth were measured. As shown in Table 1, the incorporation of ${ }^{3} \mathrm{H}-\mathrm{TdR}$ and cell number decreased markedly when the cells were treated at $37^{\circ} \mathrm{C}$. On the other hand, neither inhibition of DNA synthesis nor cell growth in vitro was observed when the cells were treated at $0^{\circ} \mathrm{C}$.

\section{Effect of Sporamycin on DNA}

\section{Polymerase}

The effect of sporamycin on DNA synthesis was studied using various kinds of DNA polymerase extracted from EHRLICH ascites cells. As shown in Table 2, sporamycin did not inhibit DNA polymerase $\alpha, \beta$ or $\gamma$, and terminal deoxynucleotidyl transferase. Although data are not shown, even when DNA template was preincubated with sporamycin before the addition of DNA polymerase, no significant inhibition was observed.

\section{Effect of Sporamycin on the Size of Cellular DNA}

HeLa cells were incubated with sporamycin for 4 hours, and the size of cellular DNA was analyzed ky alkaline sucrose gradient. Sedimentation pattern of DNA treated with $0.1 \mu \mathrm{g} / \mathrm{ml}$ of the

Table 1. Effect of temperature on sporamycin inhibition of HeLa-S3 cell growth and DNA synthesis.

\begin{tabular}{c|l|r|r}
\hline $\begin{array}{c}\text { Sporamycin } \\
(\mu \mathrm{g} / \mathrm{ml})\end{array}$ & \multicolumn{1}{|c|}{$\begin{array}{c}\text { Incubation } \\
\text { condition }\end{array}$} & $\begin{array}{c}{ }^{3} \mathrm{H}-\mathrm{TdR} \\
\text { incorporation }\end{array}$ & $\begin{array}{c}\text { Cell count }\left(\times 10^{3}\right) \\
\text { at } 72 \text { hours }\end{array}$ \\
\hline 0 & $37^{\circ} \mathrm{C}$ & $3,630(100)$ & $328(100)$ \\
10 & $37^{\circ} \mathrm{C}$ & $2,282(67)$ & $6(2)$ \\
10 & $37^{\circ} \mathrm{C}, 30 \mathrm{~min} . \rightarrow$ washed $\rightarrow 37^{\circ} \mathrm{C}$ & $2,426(67)$ & $17(5)$ \\
0 & $0^{\circ} \mathrm{C}, 30 \mathrm{~min} . \rightarrow$ washed $\rightarrow 37^{\circ} \mathrm{C}$ & $3,605(99)$ & $317(100)$ \\
10 & $0^{\circ} \mathrm{C}, 30 \mathrm{~min} . \rightarrow 37^{\circ} \mathrm{C}$ & $2,464(68)$ & $9(3)$ \\
10 & $0^{\circ} \mathrm{C}, 30 \mathrm{~min} . \rightarrow$ washed $\rightarrow 37^{\circ} \mathrm{C}$ & $3,786(104)$ & $321(101)$ \\
\hline
\end{tabular}

( ); percent of control.

Table 2. Effect of sporamycin on DNA polymerizing enzymes from EHRLICH ascites carcinoma.

\begin{tabular}{c|c|c|c|c}
\hline \multirow{2}{*}{$\begin{array}{c}\text { Sporamycin } \\
(\mu \mathrm{g} / \mathrm{ml})\end{array}$} & \multicolumn{4}{|c}{$\left[{ }^{3} \mathrm{H}\right]$-TMP incorporated } \\
\cline { 2 - 5 } & Polymerase $\alpha$ & Polymerase $\beta$ & Polymerase $\gamma$ & TDT* \\
\hline 0 & $15,296(100)$ & $3,120(100)$ & $4,997(100)$ & $4,982(100)$ \\
1 & $15,131(99)$ & $3,010(96)$ & $5,303(107)$ & $4,600(92)$ \\
10 & $15,700(103)$ & $3,119(100)$ & $5,082(102)$ & $4,443(89)$ \\
100 & $20,439(135)$ & $3,111(100)$ & $5,638(113)$ & $4,469(90)$ \\
\hline
\end{tabular}

\footnotetext{
* terninal deoxynucleotidyl transferase from calf thymus.
} 
Fig. 2. Alkaline sedimentation patterns of cellular DNA from HeLa cells treated with sporamycin.

HeLa cells prelabeled with ${ }^{3} \mathrm{H}-\mathrm{TdR}$ were incubated with $0.1,1$, or $10 \mu \mathrm{Ci} / \mathrm{ml}$ of sporamycin (closed circles). The cells prelabeled with ${ }^{14} \mathrm{C}$-TdR served as non-treated cells (open circles).

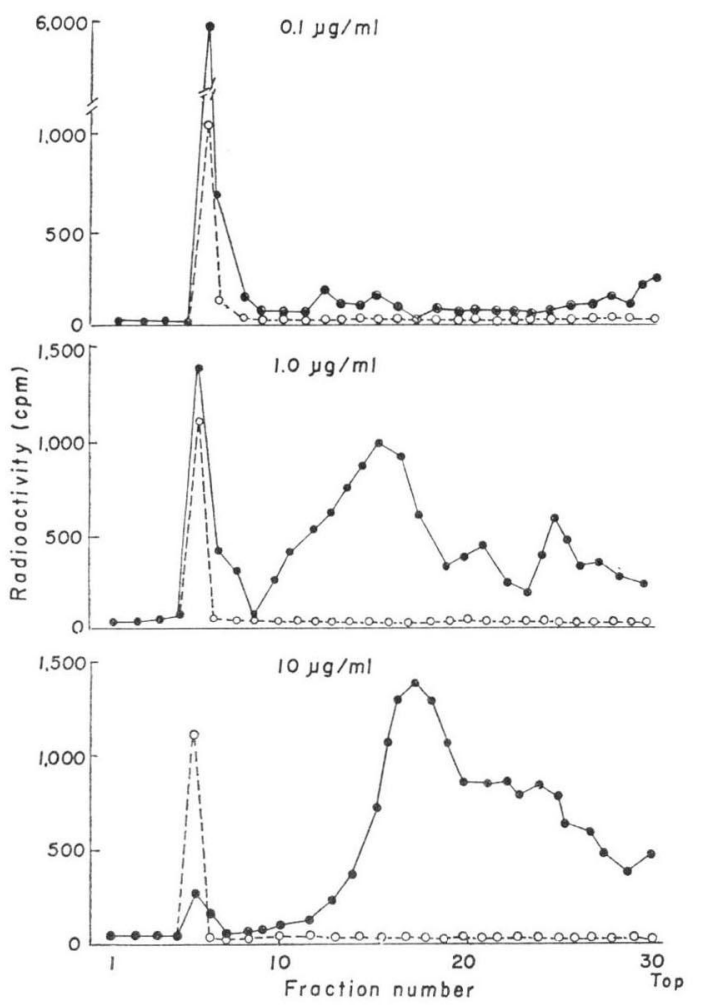

antibiotic at $37^{\circ} \mathrm{C}$ for 4 hours was similar to the non-treated one, but the change of sedimentation pattern of DNA was remarkable when treated with 1 or $10 \mu \mathrm{g} / \mathrm{ml}$ of sporamycin, and seemed to be dose dependent (Fig. 2). These data suggested that single-strand scission occurred in DNA strand of HeLa cells incubated with sporamycin. When HeLa cells were treated with the antibiotic at $0^{\circ} \mathrm{C}$ for 30 minutes, the change of sedimentation pattern was not observed (Fig. 3).
Fig. 3. Alkaline sedimentation patterns of cellular DNA of HeLa cells prelabeled with ${ }^{14} \mathrm{C}$-TdR for nontreated cells (open circles) or ${ }^{3} \mathrm{H}-\mathrm{TdR}$ for sporamycin-treated cells (closed circles) were incubated with $10 \mu \mathrm{g} / \mathrm{ml}$ of sporamycin for 30 minutes at $37^{\circ} \mathrm{C}$ or $0^{\circ} \mathrm{C}$.

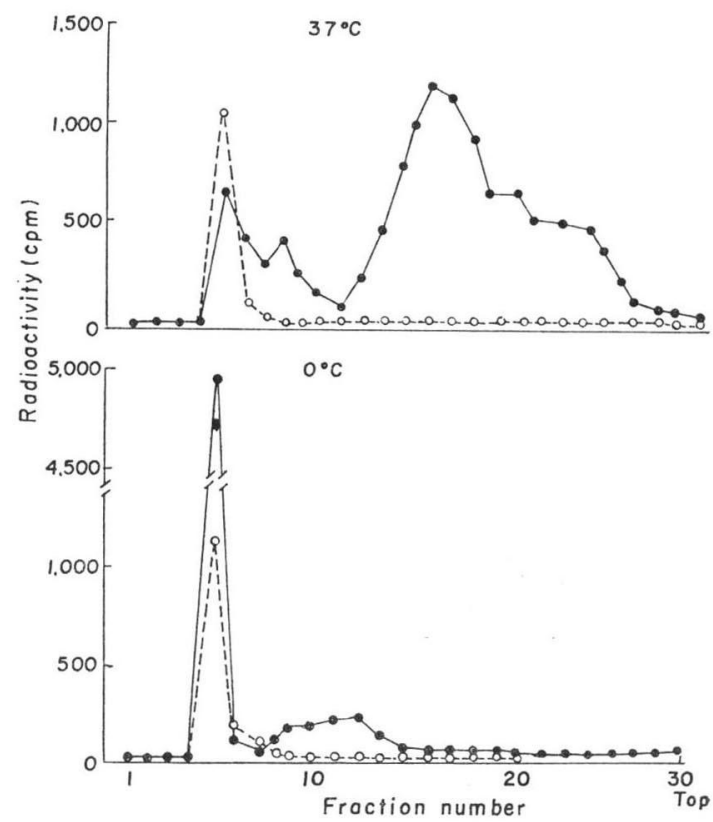

Fig. 4. Effect of sporamycin on the shift in the Tm of calf thymus DNA.

Calf thymus DNA was incubated with $10 \mu \mathrm{g} / \mathrm{ml}$ and $100 \mu \mathrm{g} / \mathrm{ml}$ of sporamycin, or without the antibiotic.

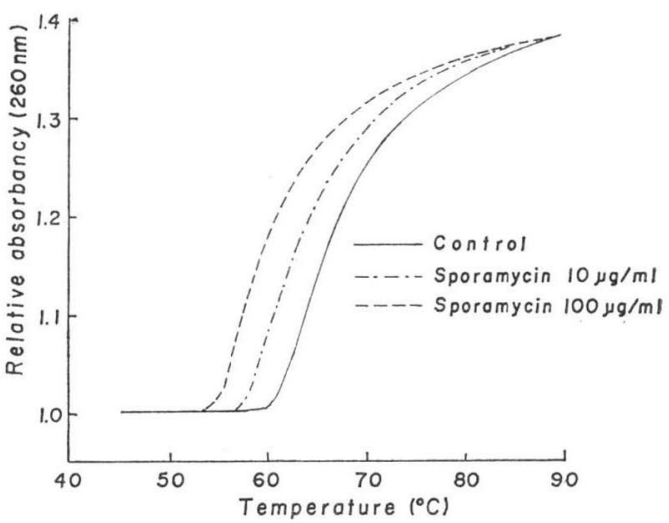

Effect of Sporamycin on Tm of the Calf Thymus DNA

The Tm of calf thymus DNA in $1 / 100 \mathrm{SSC}$ was $67^{\circ} \mathrm{C}$. When DNA was incubated with 10 or $100 \mu \mathrm{g} / \mathrm{ml}$ of sporamycin at $37^{\circ} \mathrm{C}$ for 30 minutes, the $\mathrm{Tm}$ decreased to $64^{\circ} \mathrm{C}$ or $60.5^{\circ} \mathrm{C}$, respectively. However sporamycin did not affect hyperchromicity (Fig. 4). 


\section{Discussion}

The present series of experiments showed that sporamycin inhibited DNA synthesis, while RNA and protein synthesis were not significantly affected in HeLa cells. Moreover sporamycin directly or indirectly caused single-strand scission in cellular DNA at relatively low concentration of the antibiotic. When the cells were treated with sporamycin at $0^{\circ} \mathrm{C}$ and incubated in fresh MEM at $37^{\circ} \mathrm{C}$, inhibition of the cell growth, DNA synthesis, and strand scission of cellular DNA was not observed. This mechanism is still obscure, but sporamycin dose not bind effectively to cells or physiological temperature is essential to the activation of this antibiotic.

We fcund that sporamycin induced a decrease of Tm of calf thymus DNA in vitro, but did not affect its hyperchromicity. This result suggests that sporamycin affects the hydrogen bonds of doublestranded DNA. Similar phenomenon was observed in bleomycin ${ }^{5)}$, neocarzinostatin ${ }^{6)}$, DNA unwinding protein of Escherichia coli ${ }^{7)}$, and the DNA helix-destabilizing protein ${ }^{8)}$. The former two antibiotics caused inhibition of DNA polymerase activity $^{9 \sim 12)}$, while the latter two proteins stimulate the activity of homologous DNA polymerase in vitro. However, in contrast to these agents, sporamycin did not aflect DNA polymerase activity in vitro. This indicated that the DNA template and primer in polymerase assay mixture at $37^{\circ} \mathrm{C}$ was unaffected by sporamycin.

Macromomycin, another macromolecular antibiotic, is also known to cause strand scission in cellular DNA ${ }^{13)}$, but did not affect the DNA polymerase activity ${ }^{14}$ ), or rather, stimulated it in an isolated nucleus system ${ }^{15}$. The cytotoxicity of macromomycin could be recovered by removal of the antibiotic from the binding locus by a treatment with trypsin ${ }^{13)}$. Although data are not shown, the same phenomenon was not observed in sporamycin. Recently, Suzuki et al. ${ }^{15)}$ reported that when L-5178Y cells were treated with macromomycin, the growth of the cells did not recover by trypsin treatment.

The rnode of action of sporamycin seems to be complicated, but it is considered that it has a cytocidal activity due to its primary effect on cellular DNA.

\section{Acknowledgement}

This work was partially supported by a Grant-in-Aid for Cancer Research from the Ministry of Health and Welfare and from the Ministry of Education, Science and Culture, and by a fund from Japan Keirin Association.

\section{References}

1) Umezawa, I.; K. Komiyama, H. Takeshima, J. Awaya \& S. Ōmura: A new antitumor antibiotic, PO-357. J. Antibiotics 29: 1249 1251, 1976

2) Komiyama, K.; K. Sugimoto, H. Takeshima \& I. Umezawa: A new antitumor antibiotic, sporamycin. J. Antibiotics 30: 202 208, 1977

3) Komiyama, K.; H. Takeshima \& I. Umezawa: Antitumor activity of a new antitumor antibiotic, sporamycin. Gann 68: 213 219, 1977

4) MAtsukage, A.: DNA polymerases of animal cells. I. Separation and purification of DNA polymerase $\alpha, \beta$ and $\gamma$. Tanpakushitsu Kakusan Kōso 21: 1011 1021, 1976 (in Japanese)

5) Nagai, K.; H. Yamaki, H. Suzuki, N. Tanaka \& H. Umezawa: The combinded effects of bleomycin and sulfhydryl compounds on the thermal denaturation of DNA. Biochim. Biophys. Acta 179: 165 171, 1969

6) Nakamura, T.; H. Sawada, T. Higuchi, K. Tatsumi, M. Sasada, M. Tashima, S. Shirakawa \& G. WaKISAKA: Mechanism of action of anticancer agents in relation with their inhibitory effects on the neoplastic cells. Gan-no-Rinshō 21: $681 \sim 689,1975$

7) Sigal, N.; H. Delius, T. Kornberg, M. L. Gefter \& B. Alberts: A DNA-unwinding protein isolated from Escherichia coli: It's interaction with DNA and with DNA polymerases. Proc. Natl. Acad. Sci., U.S.A. 69: $3537 \sim 3541,1972$

8) Sigematsu, T. K.; T. Enomoto, M. Yamada, M. Nakanishi \& M. Tsuboi: Exposure of DNA bases induced by the interaction of DNA and calf thymus DNA helix-destabilizing protein. Proc. Natl. Acad. Sci., U.S.A. 75: 4689 4693, 1978

9) Dicicicino, R. \& B. I. Sshai Srivastava: Effect of bleomycin on deoxynucleotide-polymerizing enzymes from human cells. Cancer. Res. 36: 1644 1668, 1976 
10) Beerman, T. A. \& I. H. Goldberg: The relationship between DNA strand scission and DNA synthesis inhibition in HeLa cells treated with neocarzinostatin. Biochim. Biophys. Acta 475: 281 293, 1977

11) Beerman, T. A.; R. Poon \& I. H. Goldberg: Single strand nicking of DNA in vitro by neocarzinostatin and its possible relationship to the mechanism of drug action. Biochim. Biophys. Acta 475: 294 306, 1977

12) Acurea, A. D.: Sequence specific cleavage of DNA by antitumor antibiotics neocarzinostatin and bleomycin. Proc. Natl. Acad. Sci., U.S.A. 75: 3608 3612, 1978

13) Beerman, T. A.: Cellular DNA damage by the antitumor protein macromomycin and relationship to cell growth inhibition. Biochem. Biophys. Res. Commun. 83: 908 914, 1978

14) Kunimoto, T.; M. Hori \& H. Umezawa: Macromomycin, an inhibitor of membrane function of tumor cells. Cancer Res. 32: $1251 \sim 1256,1972$

15) Suzuki, H.; T. Nishimura, K. Muto \& N. Tanaka: Mechanism of action of macromomycin; DNA strand scission, inhibition of DNA synthesis and mitosis. J. Antibiotics 31: 875 883, 1978 